\title{
Mineral and centesimal contents, antioxidant activity and antimicrobial action of phenolic compounds from Eugenia Brasiliensis Lam. Pulp
}

\author{
Flávia Guimarães ZOLA ${ }^{1}$, Adeline Conceição RODRIGUES ${ }^{1}$, Brígida D’Ávila OLIVEIRA ${ }^{1}$, \\ Nayara Thais Barbosa SACRAMENTO' ${ }^{1}$, Jason Guy TAYLOR ${ }^{2}$, Uelinton Manoel PINTO ${ }^{3}$, \\ Michele Corrêa BERTOLDI ${ }^{4 *}$
}

\begin{abstract}
Phenolic compounds (PC) have presented antioxidant potential as well as antimicrobial action against several bacteria. This study aimed to extract PC from grumixama (Eugenia brasiliensis Lam.) pulp using solid phase extraction (SPE), then quantify the PC by Folin-Ciocalteu assay, and to evaluate the antioxidant activity (AA) from PC by DPPH, ABTS and FRAP methods as well as its antimicrobial activity by plate diffusion assay (PDA) and Minimal Inhibitory Concentration (MIC) assays. Additionally, the centesimal composition of the fruit and its mineral content by Total Reflection X-Ray Fluorescence Spectroscopy were determined. The fruit is a good source of PC which presented a higher contribution on AA from pulp than NPHRC. Calcium was the trace element in highest concentration in the pulp, followed by iron. PC from grumixama inhibited the growth of Staphylococcus aureus, Bacillus cereus, Pseudomonas aeruginosa but not Escherichia coli and Listeria monocytogenes in the PDA. PC showed antimicrobial activity against the five microorganisms tested in the MIC assay, in which S. aureus and B. cereus were the most sensitive. This study highlights the antioxidant and antimicrobial potential of Eugenia brasiliensis Lam. as natural agent in the development of functional foods and nutraceuticals.
\end{abstract}

Keywords: antimicrobial activity; Brazilian cherry; mineral composition; phenolic compounds; grumixama.

Practical Application: Use of grumixama in Food industry as a natural source of antioxidant and antimicrobial agents.

\section{Introduction}

Brazil has one of the largest biodiversity in the world. The genus Eugenia, one of the largest in the Myrtaceae family, comprises about 400 species, which are cultivated in all national territory. It stands out because of its economic potential associated to commercial exploration of its edible fruits, essential oil, wood and ornamental plants as well as pharmacological properties. In Brazilian folk medicine, peels and leaves from the species Eugenia brasiliensis Lamark has been used for treating arthritis and rheumatism (Queiroz et al., 2015). Moreover, anti-inflammatory, antidepressant, anti-infective and anticancer activities from this specie have been studied (Colla et al., 2012; Infante et al., 2016; Lazarini et al., 2018; Magina et al., 2009; Teixeira et al., 2017).

In Brazil, there has been increased commercial interest in fruits of Eugenia brasiliensis Lam., popularly known as Grumixama or Brazilian cherry, due to its attractive sensory characteristics and its health benefits associated, in part, to the presence of phenolic compounds (Flores et al., 2012). Thus, due to its high perishability, the consumption of this fruit has been favored by commercialization of frozen pulps (Teixeira et al., 2018; Infante et al., 2016).
Antimicrobial activity of plant extracts rich in phenolic compounds against human pathogens has intensively been studied focusing in several applications including food preservation, production, development and characterization of new healthy food ingredients, medical and pharmaceutical products as well as natural therapies (Kalia, 2013; Savoia, 2012). Antimicrobial action has been attributed to multiple mechanisms and chemical structures of phytochemicals. Anthocyanins, water-soluble pigments belonging to the large class of phenolic compounds classified as flavonoids and also present in grumixama (Machado et al., 2017) have shown antioxidant and therapeutic activities as well as effects against different microbes, mainly Gram-positive bacteria (Cisowska et al., 2011; Flores et al., 2012).

Therefore, considering the bioactive potential of grumixama related to its phenolic compounds, the objectives of this study were to characterize the centesimal and mineral composition of the pulp as well as in vitro antioxidant and antimicrobial activities from its phenolic compounds in order to provide relevant data that may serve as a basis for future applications in the food and pharmaceutical industries.

${ }^{1}$ Escola de Nutrição, Universidade Federal de Ouro Preto - UFOP, Campus Morro do Cruzeiro, Ouro Preto, MG, Brasil

${ }^{2}$ Departamento de Química, Instituto de Ciências Exatas e Biológicas, Universidade Federal de Ouro Preto - UFOP, Campus Morro do Cruzeiro, Ouro Preto, MG, Brasil ${ }^{3}$ Centro de Pesquisa em Alimentos, Departamento de Alimentos e Nutrição Experimental, Faculdade de Ciências Farmacêuticas, Universidade de São Paulo - USP, São Paulo, SP, Brasil

${ }^{4}$ Departamento de Farmácia, Instituto Ciências da Vida, Universidade Federal de Juiz de Fora - UJFJ, Governador Valadares, MG, Brasil

*Corresponding author: mibertoldi@yahoo.com.br 


\section{Materials and methods}

\subsection{Phenolic extract preparation and quantification of phenolic compounds}

Fruits of E. brasiliensis Lam., purple variety, were collected in the city of Ouro Preto - MG, herborized and a voucher specimen deposited in the Professor José Badini Herbarium at the Federal University of Ouro Preto (Eugenia brasiliensis Lam., M.C.T.B. Messias \& F.G. Zola, 2481). Grumixama fruits were sanitized with $50 \mathrm{mg} / \mathrm{L}$ of sodium hypochloride for $15 \mathrm{~min}$. Pulp was manually separated from seeds (yield of $65.0 \mathrm{~g}$ pulp/100 $\mathrm{g}$ fresh fruit), homogenized and kept frozen at $-20{ }^{\circ} \mathrm{C}$ until use.

Phenolic compounds (PC) were extracted using solid phase extraction (SPE), as previously described by Rodrigues et al. (2016b). This technique was employed for the removal of non-phenolic hydrosoluble reducing compounds (NPHRC), such as sugars and organic acids, which could mask the quantification and activity from the compounds of interest and its use has increased because it is quick, efficient, requires very small volumes of organic solvents and is suitable for aqueous samples (Castro \& Molina, 2012). Briefly, thawed grumixama pulp (100 g) was macerated with 1:1:1 (v/v/v) ethanol:methanol:acetone solution, filtered, solvents were evaporated using a rotary evaporator at $40{ }^{\circ} \mathrm{C}$ and resupended in distilled water to obtain the crude extract. Crude extract (CE) was loaded into a C18 Waters Sep-Pak Vac $35 \mathrm{cc} 10 \mathrm{~g} 20 \mathrm{~cm}^{3}$ minicolumns (Waters Corporation, Milford, MA), where the phenolic compounds were adsorbed. Elution of polyphenolics was performed with methanol, which was later evaporated. Subsequently, distilled water was added up to a known volume and the extract rich in phenolic compounds was finally named "phenolic extract" (PE), denoting an extract rich in phenolic compounds. The total phenolic content (TPC) of the extracts was determined by the Folin-Ciocalteu assay (Shahidi \& Naczk, 1995). Gallic acid (0-200 mg/L) was used as standard and results were expressed as $\mathrm{mg}$ gallic acid equivalent (GAE)/100 g pulp (in wet and dry weight basis).

\subsection{Centesimal composition}

Contents of moisture, ash, total lipids, total soluble solutes, proteins, carbohydrates and fibers from E. brasiliensis Lam. pulp were analyzed according to methods described by Association of Official Analytical Chemists $(1995,2003,2005)$ and Instituto Adolfo Lutz (2005) and expressed in percentage (g/100g pulp). Total carbohydrate content was calculated by the difference between $100 \%$ and the sum of the contents of protein, total lipids, moisture and ash. The experiment was performed in triplicate and the results were expressed as average and standard deviation.

\subsection{Mineral quantification}

The contents of potassium, calcium, iron, zinc, chloride, chromium, nickel, manganese and copper were analyzed by Total Reflection X-Ray Fluorescence (TXRF), as previously described Oliveira et al. (2016). The analysis was performed on a S2-PICOFOX instrument (Bruker AXS, Berlin, Germany) with a molybdenum anode operating at $50 \mathrm{kV}$ and $750 \mathrm{~mA}$. Data were obtained by integration of the signal on a Bruker
Spectra software, version 6.1.5.0. Quantification of minerals was performed using internal standards and expressed as $\mathrm{mg} / \mathrm{g}$ pulp (wet weight).

\subsection{Antioxidant activity}

Antioxidant capacity (AA) from phenolic extracts was determined by radical cation 2,2'-azino-bis(3-ethylbenzothiazolin e-6-sulphonic acid (ABTS) method according to Cai et al. (2004). Trolox $(0-2000 \mu \mathrm{M})$ was used as external standard and AA was expressed as $\mu \mathrm{mol}$ Trolox equivalent antioxidant capacity (TEAC)/g pulp. Additionally, AA was evaluated by the stable free radical 2, 2 - diphenyl - 1 -picrylhydrazyl (DPPH) method, as described by Brand-Williams et al. (1995), and expressed as Half-maximal inhibitory concentration (IC50) or concentration of extract that provides $50 \%$ inhibition of DPPH absorbance, which was expressed in terms of $\mathrm{mg}$ GAE/L of extract and $\mathrm{g}$ of pulp/L of extract. AA was also evaluated in terms of ferric-reducing antioxidant power (FRAP), which was estimated according to procedures described by Benzie \& Strain (1996). Standard aqueous solutions of iron (II) sulfate heptahydrate $\left(\mathrm{FeSO}_{4} .7 \mathrm{H}_{2} \mathrm{O}\right)$ in concentrations ranging from $500-2000 \mu \mathrm{M}$ were used for calibration. AA from phenolic extract was expressed as $\mu \mathrm{mol}$ $\mathrm{Fe}^{+2} / \mathrm{g}$ pulp. Experiments were conducted in triplicate.

\subsection{Antimicrobial Activity}

The antimicrobial activity of the phenolic extract was determined by plate diffusion assay (PDA) and minimal inhibitory concentration (MIC) assays. The tests were performed against Gram negative (Escherichia coli ATCC10536 and Pseudomonas aeruginosa ATCC15442) and Gram positive (Staphylococcus aureus ATCC6538P, Listeria monocytogene ATCC7644 and Bacillus cereus ATCC 11778) bacteria, all of great relevance in food microbiology. PDA was performed as described by Salawu et al. (2011), while MIC assay was determined following the method of Wiegand et al. (2008). Antimicrobial activity determined by PDA was expressed by means of three measures of the difference between the diameter of zones of bacterial growth inhibition around the wells $(\mathrm{mm})$ minus the diameter of each well $(\mathrm{mm})$, for each concentration of the phenolic extract. The minimal concentration of phenolic extract from E. brasiliensis Lam. able to inhibit bacterial growth (MIC) was expressed as mg GAE/L of phenolic extract and g pup (in wet and dry weight basis)/L, followed the extract dilution.

\section{Results and discussion}

\subsection{Centesimal composition}

The results of the centesimal composition of grumixama pulp are presented in Table 1.

The high moisture content of grumixama pulp, which vary from 83.7 to $93.6 \mathrm{~g} / 100 \mathrm{~g}$, is a common characteristic of fruits from Myrtaceae family (Aguiar et al., 2016; Nascimento et al., 2017; Rodrigues et al., 2016a; Teixeira et al., 2015), which confers succulence to these fruits. Similar values for centesimal composition of grumixama pulp, in wet weight basis, was within the range of values reported in the literature, varying from 
Table 1. Centesimal composition of grumixama pulp (g/100 g pulp).

\begin{tabular}{ccc}
\hline & $\begin{array}{c}\text { g/100 g pulp, } \\
\text { wet weight }\end{array}$ & $\begin{array}{c}\text { g/100 g pulp, } \\
\text { dry weight }\end{array}$ \\
\hline Proteins & $0.39 \pm 0.01$ & $3.96 \pm 0.10$ \\
Lipids & $0.02 \pm 0.01$ & $0.20 \pm 0.10$ \\
Ash & $0.36 \pm 0.00$ & $3.65 \pm 0.00$ \\
Moisture & $90.15 \pm 0.97$ & $\mathrm{NA}^{\mathrm{b}}$ \\
Carbohydrates & $9.08 \pm 0.00^{\mathrm{a}}$ & $92.18 \pm 0.00$ \\
Fibers & $1.25 \pm 0.05$ & $12.69 \pm 0.51$ \\
Total soluble solutes $\left({ }^{\circ}\right.$ Brix $)$ & $5.00 \pm 0.20$ & $50.76 \pm 2.00$ \\
\hline
\end{tabular}

Values are mean of triplicates \pm standard deviation; ${ }^{a}$ Value obtained by the difference $100 \%$ - (protein, lipid, moisture and ash contents); ${ }^{\mathrm{b}} \mathrm{NA}$ - not applicable.

0.27 to $0.66 \mathrm{~g} / 100 \mathrm{~g}$ for protein content, 0.23 to $0.61 \mathrm{~g} / 100 \mathrm{~g}$ for ash content, 4.20 to $8.26 \mathrm{~g} / 100 \mathrm{~g}$ for carbohydrate content, 3.08 to $4.65 \mathrm{~g} / 100 \mathrm{~g}$ for total fiber content and 0.01 to $0.26 \mathrm{~g} / 100 \mathrm{~g}$ for lipid content (Aguiar et al., 2016; Silva et al. 2014; Teixeira et al., 2015). On the other hand, Silva et al. (2014) did not detect levels of lipids in grumixama confirming that this fruit is not a source of fat. The total soluble solids content ( $\left.{ }^{\circ} \mathrm{Brix}\right)$ from grumixama pulp was $5.0^{\circ} \mathrm{Brix}$, the same value reported by Aguiar et al. (2016), but below what was found by Silva et al. (2014) of $9.4^{\circ}$ Brix. Variations in centesimal composition according to variety (purple and yellow fruits) and cultivation place have been shown in the literature (Teixeira et al., 2015).

Considering the centesimal composition of grumixama pulp, the inclusion of this fruit in a regular diet could contribute to provide the right amounts of nutrients for a good health (Brasil, 2005).

\subsection{Minerals content}

As can be seen in Table 2, the most abundant element detected in grumixama pulp was calcium (3.23 $\mathrm{mg} / \mathrm{g}$ pulp) followed by iron $(1.54 \mathrm{mg} / \mathrm{g})$ and potassium $(0.84 \mathrm{mg} / \mathrm{g})$. The mineral content of grumixama may vary acoording to the maturation stage of the fruit, as reported by Nehring (2016), who found values ranging from 0.73 to $1.49 \mathrm{mg} / \mathrm{g}$ for calcium and from 3.61 to $5.89 \mathrm{mg} / \mathrm{g}$ for potassium, depending on the maturation stage. Similar values of calcium (3.36 mg/g pulp), potassium $(0.90 \mathrm{mg} / \mathrm{g})$ and iron (0.60 mg/g) were found for pitanga (Eugenia uniflora) pulp, another species from genus Eugenia (Rodrigues et al., 2016b).

Accorging to World Health Organization, the daily consumption of 400 grams or five portions a day of fruit and vegetables is recomemnded for adults to prevent chronic non-communicable diseases (World Health Organization, 2018). Therefore, the daily consumption of a $100 \mathrm{~g}$ portion of grumixama pulp, which is equivalent to $153 \mathrm{~g}$ of fruit or 38 fruits (4g each fruit), would exceed the needs of adults for ingestion of iron (Reference Daily Intake or RDI of $14 \mathrm{mg} /$ day), zinc (RDI of $7 \mathrm{mg} /$ day), chromium (RDI of $35 \mu \mathrm{g} /$ day) and manganese (RDI of $2.3 \mathrm{mg} /$ day) (Brasil, 2005) Furthermore, the fruit presents high level of calcium (32.3\% of DRI of $1000 \mathrm{mg} /$ day, for adults) (Brasil, 2012) and thus, its regular consumption could contribute to a healthier diet. As far as we know, no studies that applied Total Reflection $\mathrm{X}$-ray Fluorescence method to quantify the mineral content
Table 2. Content of trace elements found in grumixama (mg/g pulp).

\begin{tabular}{lccc}
\hline \multicolumn{1}{c}{ Metal } & $\begin{array}{c}\text { mg/g, wet } \\
\text { weight }\end{array}$ & $\begin{array}{c}\text { mg/g, dry } \\
\text { weight }\end{array}$ & $\begin{array}{c}\text { Relative } \\
\text { Standard } \\
\text { Deviation (\%) }\end{array}$ \\
\hline Potassium (K) & 0.84 & 8.53 & 3.7 \\
Calcium (Ca) & 3.23 & 32.79 & 1.2 \\
Iron (Fe) & 1.54 & 15.63 & 0.8 \\
Zinc (Zn) & 0.21 & 2.13 & 1.6 \\
Chlorine (Cl) & $\mathrm{NF}^{\mathrm{a}}$ & $\mathrm{NF}^{\mathrm{a}}$ & $\mathrm{NA}^{\mathrm{b}}$ \\
Chromium $(\mathrm{Cr})$ & 0.49 & 4.97 & 1.9 \\
Nickel $(\mathrm{Ni})$ & 0.13 & 1.31 & 2.6 \\
Copper $(\mathrm{Cu})$ & $\mathrm{NF}$ & $\mathrm{NF}^{\mathrm{a}}$ & $\mathrm{NA}^{\mathrm{b}}$ \\
Manganese $(\mathrm{Mn})$ & 0.05 & 0.51 & 9.0 \\
\hline Values are mean of triplicates; ${ }^{\mathrm{b} F}-$ not found; ${ }^{\mathrm{b}} \mathrm{NA}-$ not applicable.
\end{tabular}

of this fruit were found in the literature to date. Information regarding mineral content of grumixama is a good contribution to foment its commercial demand and to stimulate the cultivation of this species in Brazil.

\subsection{Phenolic compounds content}

TPC of the crude (CE) and phenolic (PE) extracts of grumixama were $163.67 \mathrm{mg} \mathrm{GAE} / 100 \mathrm{~g}$ fresh fruit $(252.00 \mathrm{mg} \mathrm{GAE} / 100 \mathrm{~g}$ pulp, in wet weight basis or $2558.37 \mathrm{mg} \mathrm{GAE} / 100 \mathrm{~g}$ pulp, in dry weight basis) and $146.39 \mathrm{mg} \mathrm{GAE} / 100 \mathrm{~g}$ fresh fruit (or $225.45 \mathrm{mg}$ GAE/100 g pulp, in wet weight basis or $2288.32 \mathrm{mg} \mathrm{GAE} / 100 \mathrm{~g}$ pulp, in dry weight basis), respectively. These results were similar to those found by Silva et al. (2014) reporting $145.2 \mathrm{mg} \mathrm{GAE} / 100 \mathrm{~g}$ fresh fruit and by Infante et al. (2016) of $2.669 \mathrm{mg} \mathrm{GAE} / 100 \mathrm{~g}$ of pulp (dry weight).

A large variation on TPC from plant materials are expected due to extrinsic (methods, solvents) and intrinsic factors (variety, maturation stage) (Nehring, 2016; Teixeira et al., 2015). Nehring (2016) demonstraded the large variation of TPC from grumixama pulp according to maturation stage (38\% to $75 \%$ ), cultivation place (25\%) and the extraction mechanism and solvent types, found TPC ranging from 131 to $609 \mathrm{mg} \mathrm{GAE} / 100 \mathrm{~g}$ fresh pulp of grumixama for fifteen different solvent systens. Additionally, the type of grumixama influences its phytochemical content as demonstrated by Teixeira et al. (2015), who found higher levels of anthocyanins and flavonols for purple grumixama (32-180 mg/100g fresh pulp) than for yellow fruit $(13-41 \mathrm{mg} / 100 \mathrm{~g}$ fresh pulp). Moreover, the presence of non-phenolic hydrosoluble reducing compounds (NPHRC) such as ascorbic acid and reducing sugars in the extract, may cause overestimation of TPC, as demonstrated in the study conducted by Rodrigues et al. (2016b), because Folin-Ciocalteu reagent it is not specific for PC detection and, therefore, NPHRC can be oxidized (Huang et al., 2005). In the present study, the reduction in TPC of the PE from grumixama as compared to the CE's TPC was approximately $10.6 \%$.

Studies have reported TPC from tropical fruits varying from 13.5 to $1176 \mathrm{mg} \mathrm{GAE} / 100 \mathrm{~g}$ fresh weight (Contreras-Calderón et al., 2011; Rufino et al., 2010). Due to these great variations, Rufino et al. (2010) classified the TPC of fruits, in wet weight basis, as low 
(<100 mg GAE/100 g), medium (100-500 mg GAE/100 g) and high ( $>500 \mathrm{mg}$ GAE$/ 100 \mathrm{~g}$ ). Based on this classification, grumixama presented a medium TPC. However, fruits of the same species could fit into more than one range of TPC, since variations in the composition of phytochemicals in plant materials may occur, as previously mentioned. Pitanga, for instance, may be classified as a fruit with medium-to-high content of phenolic compounds, because a large variation on TPC (95.0 - 799.8 mg GAE/100g fresh weight) of pitanga pulp has been found (Abe et al., 2012; Bagetti et al., 2011; Denardin et al., 2015; Rodrigues et al., 2016b).

The major PC identified in grumixama so far includes anthocyanins (delphinidin-3-glucoside, delphinidin-3-pentoside, cyanidin-3-glucoside, cyanidin-3-galactoside, cyanidin-3-arabinoside, cyanidin-3-xyloside, malvidin-3-glucoside, delphinidin and cyanidin) but also other types of flavonoids (rutin, myricetin, quercetin, (-)-epicatechin, catechin and myricetin), ellagitannins (pedunculagin isomers, strictinin isomers and ellagic acid galloyl hexoside) as well as phenolic acids (protocatechuic acid, 4-hydroxybenzoic acid, vanillic acid, syringic acid, ellagic acid, gallic acid, chlorogenic acid, caffeic acid, ferulic acid and p-coumaric acid) (Flores et al., 2012; Infante et al., 2016; Karwowski, 2012; Lazarini et al., 2018; Machado et al., 2017; Nascimento et al., 2017; Teixeira et al., 2015).

\subsection{Antioxidant activity}

The ability of PC from grumixama to scavenge the stable free radical 2, 2 - diphenyl - 1 -picrylhydrazyl (DPPH), expressed in terms of $\mathrm{IC}_{50}$, was $595.9 \mathrm{mg} \mathrm{GAE} / \mathrm{L} \mathrm{PE}$, equivalent to $264.32 \mathrm{~g}$ fresh pulp/ L PE (26.03 g pulp/ L, in dry weight basis). A lower value of $\mathrm{IC}_{50}$ (close to $470 \mathrm{mg} / \mathrm{L}$ ) for lyophilized pulp of grumixama, which means higher antioxidant activity, was found by Infante et al. (2016). Aproximate $\mathrm{IC}_{50}$ values, ranging from 36.78 to $488,2 \mathrm{mg} \mathrm{GAE} / \mathrm{L}$, have been reported for pitanga pulp (red, purple and orange varieties), a fruit of the same genus as grumixama (Bagetti et al., 2011; Denardin et al., 2015; Rodrigues et al., 2016b). In these studies, a strong positive correlation between antioxidant activity and phenolic content of pitanga was demonstrated, suggesting that phenolic compounds are primarily responsible for the antioxidant activity of the fruits from Eugenia genus as compared to NPHRC such as ascorbic acid (Bagetti et al., 2011; Denardin et al., 2015).

PC from grumixama pulp also reduced ferric iron $\left(\mathrm{Fe}^{3+}\right)$ to ferrous ion $\left(\mathrm{Fe}^{2+}\right)$ (FRAP method) and showed AA of $42.11 \mu \mathrm{mol} \mathrm{Fe} \mathrm{Fe}^{+2} / \mathrm{g}$ fresh pulp. Proximal values of AA from grumixama extracts, varying from 18.85 to $34.87 \mu \mathrm{mol} \mathrm{Fe} \mathrm{Fe}^{+2} / \mathrm{g}$ of fresh pulp were found by Nehring, 2016. Variations might be related to the presence of NPHRC, differences in cultivation and maturation stages as well as other factors previously mentioned. Furthermore, AA for pitanga pulp extract has been published (with and without NPHR), ranging from 23.43 to $34.87 \mu \mathrm{mol}$ $\mathrm{Fe}^{+2} / \mathrm{g}$ of fresh pulp (Denardin et al., 2015; Rodrigues et al., 2016b).

The ability of PC from grumixama pulp to reduce the radical cation ABTS $\bullet+$ to ABTS was $11.59 \mu$ mol TEAC/g fresh pulp. Several studies have been shown values of AA (ABTS Assay) from tropical fruits ranging from 3 to $532 \mu \mathrm{mol}$ TEAC/g fresh pulp, but these values are also influenced to additional NPHRC that were extracted (Almeida et al., 2011; Contreras-Calderón et al., 2011). For pitanga pulp phenolic extract (without contribution of NPHRC), the AA of $8.83 \mu \mathrm{mol}$ TEAC/g fresh pulp was found by Rodrigues et al. (2016b), a value closed to result found in the present study. As far as we know, these are the first results of AA from PC of grumixama pulp determined by ABTS method, expressed in terms of TEAC.

Because of the antiradical activity is associated to TPC of grumixama pulp, which comprises mainly anthocyanins that have shown effects against different microbes (Cisowska et al., 2011; Flores et al., 2012), and of the association between PC presence and antimicrobial action in fruits and vegetables (Cisowska et al., 2011; Flores et al., 2012; Zhao et al., 2009), this study focused on microbiological effects of grumixama pulp PC.

\subsection{Antimicrobial activity}

\section{Plate diffusion assay}

Data from plate diffusion test (Table 3) demonstrated that the PE of grumixama inhibited the growth of $S$. aureus and B. cereus in concentrations of $374.8 \mathrm{mg} \mathrm{GAE} / \mathrm{L} \mathrm{PE}$ or higher. The bacterium $P$. aeruginosa also showed sensitivity to PE, but only at the highest concentration (2998.5 mg GAE/L PE). E. coli and L. monocytogenes showed no sensitivity to the PE, since no inhibition halos were observed at any given concentration. According to Oliveira et al. (2017), no inhibition of growth by the plate diffusion assay should be seen with caution since some compounds present in extracts may present charge and molecular weight characteristics that could hamper their free diffusion through the solid medium that has been employed.

Alves et al. (2000) evaluated the antimicrobial activity of $5 \mathrm{mg}$ of extract of dried leaves of pitanga diluted in dichloromethane/methanol and in water against seven microorganisms, among them $S$. aureus, E. coli, B. cereus and P. aeruginosa. The results were

Table 3. Results for plate diffusion assay: growth inhibition with different concentrations of phenolic extract of grumixama, measured as inhibition zone around the wells $(\mathrm{mm})$.

\begin{tabular}{|c|c|c|c|c|}
\hline \multirow[b]{2}{*}{ Bacteria } & \multicolumn{4}{|c|}{ Total Phenolic Content (mg GAE/L) } \\
\hline & $2998.5^{\mathrm{a}}$ & 1499.25 & 749.6 & 374.8 \\
\hline E. coli ATCC10536 & _ & - & _ & - \\
\hline P. aeruginosa ATCC15442 & $5.67 \pm 0.58$ & - & - & - \\
\hline S.aureus ATCC6538P & $13.00 \pm 1.00$ & $10.00 \pm 1.00$ & $7.67 \pm 1.53$ & $5.67 \pm 0.58$ \\
\hline L.monocitogenes ATCC764 & _ & _ & _ & _ \\
\hline B. cereus ATCC11778 & $11.00 \pm 0.58$ & $8.33 \pm 0.58$ & $7.00 \pm 1.00$ & $5.33 \pm 0.58$ \\
\hline
\end{tabular}


expressed by the diameter of the zone of inhibition, considering the following classification: $<9 \mathrm{~mm}$, inactive extract; 9-12 mm, partially active extract; $13-18 \mathrm{~mm}$, active extract; $>18 \mathrm{~mm}$, very active extract. The results for the extracts activity diluted in dichloromethane/methanol and in water, respectively, were: very active and active against $S$. aureus; partially active and inactive against $E$. coli; very active and active against $B$. cereus; inactive and active against $P$. aeruginosa. Comparing the results of the present study (Table 3) with this classification, it can be concluded that the PE of grumixama was partially active against $S$. aureus and $B$. cereus, and inactive against the other microorganisms.

Few studies on the antimicrobial effects of $\mathrm{PC}$ from grumixama pulp have been reported in the literature to date. Recently, Rodrigues et al. (2016a) reported anti-quorum sensing activity, measured by the ability of the extract to inhibit violacein production in Chromobacterium violaceum, of PE from grumixama pulp, with $119.9 \mathrm{mg}$ GAE/L being the best inhibitory concentration without any detected effect on cellular growth. Inhibition of quorum sensing has been an intensively investigated area of research since bacterial quorum sensing regulates a range of phenotypes that influence bacterial virulence (Infante et al., 2016). At the same concentration, PE presented a considerable inhibitory capacity over swarming motility in Serratia marcescens and a marginal effect against Aeromonas hydrophila motility. These same authors, in another study (Rodrigues et al., 2016b), also tested pitanga extract against the same five bacteria tested in the present study, and all of them were inhibited by that PE. Interestingly, S. aureus was the most sensitive bacterium, while $B$. cereus the least sensitive in this assay. These authors also used the classification scheme mentioned above by Alves et al. (2000), and showed that in the concentration of $3920 \mathrm{mg} \mathrm{GAE} / \mathrm{L}$, the extract was active against E. coli, $P$. aeruginosa, $S$. aureus and L. monocytogenes (Rodrigues et al., 2016b). The PE of grumixama demonstrated potential to inhibit bacterial growth, with some differences when comparing to pitanga extract, as reported by Rodrigues et al. (2016b). The differences in activity may reflect the different PC profile of the extract. In any case, the $\mathrm{PC}$ of grumixama are promising in the control of S. aureus and $B$. cereus, according to the plate diffusion assay.

\section{Minimum inhibitory concentration}

The PE of grumixama showed antimicrobial activity (Table 4) against the five microorganisms tested, with MIC values lower than $374.8 \mathrm{mg} \mathrm{GAE} / \mathrm{L}$ for $S$. aureus and B. cereus, equal to $749.6 \mathrm{mg} \mathrm{GAE} / \mathrm{L}$ for P. aeruginosa and $1499.2 \mathrm{mg} \mathrm{GAE} / \mathrm{L}$ for E. coli and L. monocytogenes.
No study regarding MIC levels of phenolic compounds of grumixama against the microorganisms tested in this work has been found to date.

Recently, Lazarini et al. (2018) evaluated the minimum inhibitory concentration (MIC) of lyophilized Eugenia brasiliensis purple pulp extract (total phenolic content of $389.88 \pm 3.48 \mathrm{mg} \mathrm{GAE} / \mathrm{g}$ lyophilized pulp) against Staphylococcus aureus, Escherichia coli, Pseudomona aeruginosa, Streptococcus mutans and Lactobacillus acidophilus and found MIC values of $62.5 \mu \mathrm{g}$ lyophilized Eugenia brasiliensis purple pulp / $\mathrm{mL}$ (equivalent to $24 \mathrm{mg} \mathrm{GAE} / \mathrm{L}$ extract) for L. acidophilus and S. aureus and $250 \mu \mathrm{g} / \mathrm{mL}$ (equivalent to $100 \mathrm{mg}$ GAE/L extract) for Pseudomona aeruginosa, Streptococcus mutans and methicillin-resistant Staphylococcus aureus. The lower MIC results found by Lazarini et al. (2018) suggest additional contribution of non-phenolic hydrosoluble reducing compounds (e.g. organic acids) on antimicrobial activity of the edible portion of this species, since these compounds might be quantified by Folin-Ciocalteu assay and contribute to increase TPC. In general, fruits from Eugenia genera have representative amounts of ascorbic acid and carotenoids (Bailão et al., 2015). Therefore, ascorbic acid (10.55 mg ascorbic acid/100 g grumixama fresh pulp) and carotenoids ( $26.5 \mu \mathrm{g}$ total carotenoids/g fresh pulp), mainly $\beta$-cryptoxanthin $(17 \mu \mathrm{g} / \mathrm{g}$ ) (Nascimento et al., 2017), might contribute to increase the antibacterial action of grumixama pulp, as previously demonstrated for plant material that contain the abovementioned compounds (Ernawita et al., 2017; Ferreira et al., 2014).

Another previous study focused on anti-quorum sensing activity of grumixama extract and shown antimicrobial activity of PE of grumixama with MIC values of $214.2 \mathrm{mg} \mathrm{GAE} / \mathrm{L}$ for C. violaceum, $149.9 \mathrm{mg} \mathrm{GAE} / \mathrm{L}$ for $S$. marcescens and $499.7 \mathrm{mg} \mathrm{GAE} / \mathrm{L}$ for A. hydrophila (Rodrigues et al., 2016a). Apart from A. hydrophila, the MIC values reported by Rodrigues et al. (2016a) are lower than those found in the current study, probably due to the differences in sensibility of microorganisms to the PC of grumixama. Studying a fruit from the Eugenia genus, Rodrigues et al. (2016b) showed the antimicrobial activity (MIC test) of PE of pitanga against the same five microorganisms used in the present study, obtaining values for MIC lower than $490 \mathrm{mg} \mathrm{GAE} / \mathrm{L}$ for all bacteria. Once again, differences in MIC values among these studies may reflect differences in type and relative levels of PC in the PE of grumixama and pitanga.

A study conducted by Zhao et al. (2009) showed the antimicrobial effect to the high content of anthocyanidins and anthocyanins (especially cyanidin derivatives) against Salmonella Enteretidis and Staphylococcus aureus. Therefore, a potential antibacterial effect from grumixama might be compared to similar antimicrobial effects found for plant material rich in

Table 4. Minimal inhibitory concentration (MIC) of phenolic extract of grumixama.

\begin{tabular}{ccr}
\hline Bacteria & mg GAE L ${ }^{-1}$ phenolic extract & g pulp (dry weight) $\mathrm{L}^{-1}$ phenolic extract \\
\hline E. coli ATCC10536 & 1499.2 & 65.5 \\
P. aeruginosa ATCC15442 & 749.6 & 32.7 \\
S.aureus ATCC6538P & $<374.8$ & $<16.4$ \\
L. monocitogenes ATCC764 & 1499.2 & 65.5 \\
B. cereus ATCC11778 & $<374.8$ & $<16.4$ \\
\hline
\end{tabular}


anthocyanins since grumixama is a fruit mainly rich in delphinidin and cyanidin derivatives (Flores et al., 2012; Infante et al., 2016; Karwowski, 2012; Machado et al., 2017).

Antimicrobial properties of Eugenia brasiliensis L. have not yet been extensively studied, especially considering its edible portion. Recently, antifungal activities of extracts from different parts (seeds, leaves and pulp) of this species against Candida albicans biofilms were demonstrated (Sardi et al., 2017). A few studies have also been conducted with essential oils extracted from leaves of E. brasiliensis. For instance, Magina et al. (2009) reported that the essential oil of this species presented antimicrobial effect against $S$. aureus, $P$. aeruginosa and E. coli. These same authors reported that the leaves of $E$. brasiliensis contain a range of bioactive compounds such as triterpenes and phenolic compounds with good potential to inhibit Gram-negative bacteria (Magina et al., 2012). Additionally, Siebert et al. (2015) reported inhibitory activity of essential oils obtained from E. brasiliensis leaves in different seasons against Staphylococcus saprophyticus and $P$. aeruginosa. Together with our work, these studies show the great potential presented by grumixama, either its leaves or its pulp, to inhibit microbial growth and activity.

\section{Conclusion}

Grumixama (Eugenia brasiliensis Lam.) pulp presents inhibitory capacity against $P$. aeruginosa, $S$. aureus and $B$. cereus due to the presence of phenolic compounds, which contributed the most to the antioxidant capacity of this fruit. Besides, the fruit can contribute to a healthier diet because it is rich in calcium and might attend the needs of adults for ingestion of Iron, Zinc, Chrome and Manganese. Thus, its bioactive properties make it a promising natural agent for future applications in the food and pharmaceutical industry.

\section{Acknowledgements}

U.M.P. acknowledges grants from CNPq-Brazil (486240/2013-4 and 457794/2014-3). ACR would like to thank CAPES-Brazil for providing scholarship. FGZ and NTBS acknowledge scholarships from Universidade Federal de Ouro Preto.

\section{References}

Abe, L. T., Lajolo, F. M., \& Genovese, M. I. (2012). Potential dietary sources of ellagic acid and other antioxidants among fruits consumed in Brazil: jabuticaba (Myrciaria jaboticaba (Vell.) Berg). Journal of the Science of Food and Agriculture, 92(8), 1679-1687. http://dx.doi. org/10.1002/jsfa.5531. PMid:22173652.

Aguiar, T. M., Sabaa-Srur, A. U. O., \& Smith, R. E. (2016). Study of Grumixama (Eugenia brasiliensis, Lam) fruit pulp and development of a jelly: rheological, sensorial and colorimetric evaluation. The Natural Products Journal, 6(2), 142-151. http://dx.doi.org/10.2174 /2210315506999160506110340.

Almeida, M. M. B., Sousa, P. H. M., Arriaga, Â. M. C., Prado, G. M., Magalhães, C. E. C., Maia, G. A., \& Lemos, T. L. G. (2011). Bioactive compounds and antioxidant activity of fresh exotic fruits from northeastern Brazil. Food Research International, 44(7), 2155-2159. http://dx.doi.org/10.1016/j.foodres.2011.03.051.
Alves, T. M. D. A., Silva, A. F., Brandão, M., Grandi, T. S. M., Smânia, E. F. A., Smânia, A. Jr., \& Zani, C. L. (2000). Biological screening of brazilian medicinal plants. Memorias do Instituto Oswaldo Cruz, 95(3), 367-373. http://dx.doi.org/10.1590/S0074-02762000000300012. PMid:10800195.

Association of Official Analytical Chemists - AOAC. (1995). Official methods of analysis of AOAC international (16th ed.). Arlington. AOAC International.

Association of Official Analytical Chemists - AOAC. (2003). Official methods of analysis of AOAC international (17th ed.). Gaithersburg. AOAC International.

Association of Official Analytical Chemists - AOAC. (2005). Official methods of analysis of AOAC international. (18th ed.). Gaithersburg. AOAC International.

Bagetti, M., Facco, E. M. P., Piccolo, J., Hirsch, G. E., Rodriguez-Amaya, D., Kobori, C. N., Vizzotto, M., \& Emanuelli, T. (2011). Physicochemical characterization and antioxidant capacity of pitanga fruits (Eugenia uniflora L.). Food Science and Technology, 31(1), 147-154. http:// dx.doi.org/10.1590/S0101-20612011000100021.

Bailão, E. F. L. C., Devilla, I. A., Conceição, E. C., \& Borges, L. L. (2015). Bioactive compounds found in brazilian cerrado fruits. International Journal of Molecular Sciences, 16(10), 23760-23783. http://dx.doi. org/10.3390/ijms161023760. PMid:26473827.

Benzie, I. F. F., \& Strain, J. J. (1996). The Ferric Reducing Ability of Plasma (FRAP) as a measure of "antioxidant power": the FRAP assay. Analytical Biochemistry, 239(1), 70-76. http://dx.doi.org/10.1006/ abio.1996.0292. PMid:8660627.

Brand-Williams, W., Cuvelier, M. E., \& Berset, C. (1995). Use of a free radical method to evaluate antioxidant activity. Food Science and Technology, 28(1), 25-30.

Brasil. Agência Nacional de Vigilância Sanitária, Ministério da Saúde. (2005). Aprova o Regulamento técnico sobre a ingestão diária recomendada (IDR) de proteína, vitaminas e minerais (Resolução $\mathrm{RDC} \mathrm{n}^{\circ} 269$, de 22 de setembro de 2005). Diário Oficial da República Federativa do Brasil.

Brasil. Agência Nacional de Vigilância Sanitária, Ministério da Saúde. (2012). Dispõe o Regulamento técnico sobre informação nutricional complementar (Resolução RDC nº 54, de 12 de novembro de 2012). Diário Oficial da República Federativa do Brasil.

Cai, Y., Luo, Q., Sun, M., \& Corke, H. (2004). Antioxidant activity and phenolic compounds of 112 traditional chinese medicinal plants associated with anticancer. Life Sciences, 74(17), 2157-2184. http:// dx.doi.org/10.1016/j.lfs.2003.09.047. PMid:14969719.

Castro, M. D. L., \& Molina, M. A. (2012). Green sample preparation with non-chromatographic separation techniques. In M. L. Guardia, \& S. Garrigues (Eds.), Handbook of green analytical chemistry (chap. 8, pp. 125-151). United Kingdom: Wiley.

Cisowska, A., Wojnicz, D., \& Hendrich, A. B. (2011). Anthocyanins as antimicrobial agents of natural plant origin. Natural Product Communications, 6(1), 149-156. PMid:21366068.

Colla, A. R., Machado, D. G., Bettio, L. E., Colla, G., Magina, M. D., Brighente, I. M., \& Rodrigues, A. L. (2012). Involvement of monoaminergic systems in the antidepressant-like effect of Eugenia brasiliensis Lam. (Myrtaceae) in the tail suspension test in mice. Journal of Ethnopharmacology, 143(2), 720-731. http://dx.doi. org/10.1016/j.jep.2012.07.038. PMid:22884868.

Contreras-Calderón, J., Calderón-Jaimes, L., Guerra-Hernández, E., \& Garcia-Villanova, B. (2011). Antioxidant capacity, phenolic content and vitamin $\mathrm{C}$ in pulp, peel and seed from 24 exotic fruits from 
Colombia. Food Research International, 44(7), 2047-2053. http:// dx.doi.org/10.1016/j.foodres.2010.11.003.

Denardin, C. C., Hirsch, G. E., da Rocha, R. F., Vizzotto, M., Henriques, A. T., Moreira, J. C., Guma, F. T. C. R., \& Emanuelli, T. (2015). Antioxidant capacity and bioactive compounds of four Brazilian native fruits. Journal of Food and Drug Analysis, 23(3), 387-398. http://dx.doi.org/10.1016/j.jfda.2015.01.006. PMid:28911695.

Ernawita, Wahyuono, R. A., Hesse, J., Hipler, U. C., Elsner, P., \& Böhm, V. (2017). In vitro lipophilic antioxidant capacity, antidiabetic and antibacterial activity of citrus fruits extracts from Aceh, Indonesia. Antioxidants, 6(1), 11. http://dx.doi.org/10.3390/antiox6010011. PMid:28165379.

Ferreira, J. C. C. Fo., Gondim, B. L. C., Cunha, D. A., Figueiredo, C. C., \& Valença, A. M. G. (2014). Physical properties and antibacterial activity of herbal tinctures of calendula (Calendula officinalis L.) and cashew tree (Anacardium occidentale L.). Brazilian Research in Pediatric Dentistry and Integrated Clinic, 14(1), 49-53.

Flores, G., Dastmalchi, K., Paulino, S., Whalen, K., Dabo, A. J., Reynertson, K. A., Foronjy, R. F., D’Armiento, J. M., \& Kennelly, E. J. (2012). Anthocyanins from Eugenia brasiliensis edible fruits as potential therapeutics for COPD treatment. Food Chemistry, 134(3), 1256-1262. http://dx.doi.org/10.1016/j.foodchem.2012.01.086. PMid:25005941.

Huang, D., Ou, B., \& Prior, R. L. (2005). The chemistry behind antioxidant capacity assays. Journal of Agricultural and Food Chemistry, 53(6), 1841-1856. http://dx.doi.org/10.1021/jf030723c. PMid:15769103.

Infante, J., Rosalen, P. L., Lazarini, J. G., Franchin, M., \& Alencar, S. M. (2016). Antioxidant and anti-inflammatory activities of unexplored brazilian native fruits. PLoS One, 11(4), e0152974. http://dx.doi. org/10.1371/journal.pone.0152974. PMid:27050817.

Instituto Adolfo Lutz - IAL. (2005). Normas analíticas do Instituto Adolfo Lutz: métodos químicos e físicos para análise de alimentos (versão 4, 4. ed.). Brasília: IAL.

Kalia, V. C. (2013). Quorum sensing inhibitors: an overview. Biotechnology Advances, 31(2), 224-245. http://dx.doi.org/10.1016/j. biotechadv.2012.10.004. PMid:23142623.

Karwowski, M. S. M. (2012). Estudo da estabilidade, comportamento reológico e dos compostos fenólicos de frutas da Mata Atlântica (Dissertação de Mestrado). Universidade Federal do Paraná, Curitiba.

Lazarini, J. G., Sardi, J. C. O., Franchin, M., Nani, B. D., Freires, I. A., Infante, J., Paschoal, J. A. R., Alencar, S. M., \& Rosalen, P. L. (2018). Bioprospection of Eugenia brasiliensis, a Brazilian native fruit, as a source of anti-inflammatory and antibiofilm compounds. Biomedicine and Pharmacotherapy, 102, 132-139. http://dx.doi.org/10.1016/j. biopha.2018.03.034. PMid:29550636.

Machado, A. P. D. F., Pereira, A. L. D., Barbero, G. F., \& Martínez, J. (2017). Recovery of anthocyanins from residues of Rubus fruticosus, Vaccinium myrtillus and Eugenia brasiliensis by ultrasound assisted extraction, pressurized liquid extraction and their combination. Food Chemistry, 231, 1-10. http://dx.doi.org/10.1016/j.foodchem.2017.03.060. PMid:28449984.

Magina, M. D. A., Dalmarco, E. M. D., Dalmarco, J. B., Colla, G., Pizzolatti, M. G., \& Brighente, I. M. C. (2012). Bioactive triterpenes and phenolics of leaves of Eugenia brasiliensis. Quimica Nova, 35(6), 1184-1188. http://dx.doi.org/10.1590/S0100-40422012000600022.

Magina, M. D., Dalmarco, E. M., Wisniewski, A. Jr, Simionatto, E. L., Dalmarco, J. B., Pizzolatti, M. G., \& Brighente, I. M. (2009). Chemical composition and antibacterial activity of essential oils of Eugenia species. Journal of Natural Medicines, 63(3), 345-350. http://dx.doi. org/10.1007/s11418-009-0329-5. PMid:19308653.
Nascimento, L. S. M., Santiago, M. C. P. A., Oliveira, E. M. M., Borguini, R. G., Braga, E. C. O., Martins, V. C., Pacheco, S., Souza, M. C., \& Gogoy, R. L. O. (2017). Characterization of bioactive compounds in Eugenia brasiliensis Lam. (Grumixama). Nutrition and Food Technology, 3(3), 1-7. http://dx.doi.org/10.16966/2470-6086.146.

Nehring, P. (2016). Avaliação da capacidade antioxidante e compostos fenólicos em diferentes estádios de maturação da grumixama (Eugenia brasiliensis Lamarck). (Dissertação de Mestrado). Universidade Federal de Santa Catarina, Florianópolis.

Oliveira, B. D. A., Rodrigues, A. C., Bertoldi, M. C., Taylor, J. G., \& Pinto, U. M. (2017). Microbial control and quórum sensing inhibition by phenolic compounds of acerola (Malpighia emarginata). International Food Research Journal, 24(5), 2228-2237.

Oliveira, B. D. A., Rodrigues, A. C., Cardoso, B. M. I., Ramos, A. L. C. C., Bertoldi, M. C., Taylor, J. G., Cunha, L. R., \& Pinto, U. M. (2016). Antioxidant, antimicrobial and anti-quorum sensing activities of Rubus rosaefolius phenolic extract. Industrial Crops and Products, 84, 59-66. http://dx.doi.org/10.1016/j.indcrop.2016.01.037.

Queiroz, J. M. G., Suzuki, M. C. M., Motta, A. P. R., Nogueira, J. M. R., \& Carvalho, E. M. (2015). Popular and scientific aspects of Eugenia species use as herbal. Revista Fitos, 9(2), 73-159. http://dx.doi. org/10.5935/2446-4775.20150008.

Rodrigues, A. C., Oliveira, B. D. A., Silva, E. R., Sacramento, N. T. B., Bertoldi, M. C., \& Pinto, U. M. (2016a). Anti-quorum sensing activity of phenolic extract from Eugenia brasiliensis (Brazilian cherry). Food Science and Technology, 36(2), 337-343. http://dx.doi. org/10.1590/1678-457X.0089.

Rodrigues, A. C., Zola, F. G., Oliveira, B. D. A., Sacramento, N. T. B., Silva, E. R., Bertoldi, M. C., Taylor, J. G., \& Pinto, U. M. (2016b). Quorum Quenching and Microbial Control through Phenolic Extract of Eugenia Uniflora Fruits. Journal of Food Science, 81(10), 25382544. http://dx.doi.org/10.1111/1750-3841.13431. PMid:27603708.

Rufino, M. S. M., Alves, R. E., Brito, E. S., Pérez-Jiménez, J., SauraCalixto, F., \& Mancini-Filho, J. (2010). Bioactive compounds and antioxidant capacities of 18 non-traditional tropical fruits from Brazil. Food Chemistry, 121(4), 996-1002. http://dx.doi.org/10.1016/j. foodchem.2010.01.037.

Salawu, S. O., Ogundare, A. O., Ola-Salawu, B. B., \& Akindahunsi, A. A. (2011). Antimicrobial activities of phenolic containing extracts of some tropical vegetables. African Journal of Pharmacy and Pharmacology, 5(4), 486-492.

Sardi, J. C., Freires, I. A., Lazarini, J. G., Infante, J., Alencar, S. M., \& Rosalen, P. L. (2017). Unexplored endemic fruit species from Brazil: Antibiofilm properties, insights into mode of action, and systemic toxicity of four Eugenia spp. Microbial Pathogenesis, 105, 280-287. http://dx.doi.org/10.1016/j.micpath.2017.02.044. PMid:28259673.

Savoia, D. (2012). Plant-derived antimicrobial compounds: alternatives to antibiotics. Future Microbiology, 7(8), 979-990. http://dx.doi. org/10.2217/fmb.12.68. PMid:22913356.

Shahidi, F. Z., \& Naczk, M. (1995). Food phenolics: sources, chemistry, effects and applications (1st ed.). Lancaster: Technomic Publishing Co.

Siebert, D. A., Tenfen, A., Yamanaka, C. N., Cordova, C. M., Scharf, D. R., Simionatto, E. L., \& Alberton, M. D. (2015). Evaluation of seasonal chemical composition, antibacterial, antioxidant and anticholinesterase activity of essential oil from Eugenia brasiliensis Lam. Natural Product Research, 29(3), 289-292. http://dx.doi.org/ 10.1080/14786419.2014.958736. PMid:25219800.

Silva, N. A., Rodrigues, E., Mercadante, A. Z., \& Rosso, V. V. (2014). Phenolic compounds and carotenoids from four fruits native from the Brazilian Atlantic Forest. Journal of Agricultural and Food 
Chemistry, 62(22), 5072-5084. http://dx.doi.org/10.1021/jf501211p. PMid:24780053.

Teixeira, L. L., Bertoldi, F. C., Lajolo, F. M., \& Hassimotto, N. M. A. (2015). Identification of ellagitannins and flavonoids from Eugenia brasilienses Lam. (Grumixama) by HPLC-ESI-MS/MS. Journal of Agricultural and Food Chemistry, 63(22), 5417-5427. http://dx.doi. org/10.1021/acs.jafc.5b01195. PMid:25990484.

Teixeira, L. L., Costa, G. R., Dörr, F. A., Ong, T. P., Pinto, E., Lajolo, F. M., \& Hassimotto, N. M. A. (2017). Potential antiproliferative activity of polyphenol metabolites against human breast cancer cells and their urine excretion pattern in healthy subjects following acute intake of a polyphenol-rich juice of grumixama (Eugenia brasiliensis Lam.). Food \& Function, 8(6), 2266-2274. http://dx.doi.org/10.1039/ C7FO00076F. PMid:28541359.

Teixeira, L. L., Hassimotto, N. M. A., \& Lajolo, F. M. (2018). Grumixama - Eugenia brasiliensis Lam. In S. Rodrigues, E. O. Silva, \& E. S. Brito
(Eds.), Exotic fruits reference guide (pp. 219-224). Massachusetts: Academic Press. http://dx.doi.org/10.1016/B978-0-12-8031384.00028-9.

Wiegand, I., Hilpert, K., \& Hancock, R. E. W. (2008). Agar and broth dilution methods to determine the minimal inhibitory concentration (MIC) of antimicrobial substance. Nature Protocols, 3(2), 163-175. http://dx.doi.org/10.1038/nprot.2007.521. PMid:18274517.

World Health Organization - WHO. (2018). Global strategy on diet, physical activity and health. Geneva: WHO. Retrieved from http:// www.who.int/dietphysicalactivity/publications/releases/pr84/en/

Zhao, X., Zhang, C., Guigas, C., Ma, Y., Corrales, M., Tauscher, B., \& Hu, X. (2009). Composition, antimicrobial activity, and antiproliferative capacity of anthocyanin extracts of purple corn (Zea mays L.) from China. European Food Research and Technology, 228(5), 759-765. http://dx.doi.org/10.1007/s00217-008-0987-7. 